\title{
THE USE OF POSSE (PREDICT, ORGANIZE, SEARCH, SUMMARIZE, AND EVALUATE) STRATEGY TO IMPROVE STUDENTS' READING COMPREHENSION IN NARRATIVE TEXT AT THE TENTH GRADE OF SMK PGRI 2 DENPASAR IN THE ACADEMIC YEAR 2019/2020
}

\author{
Vety Isma Ulfa \\ English Language Education, Dwijendra University \\ e-mail: vetyismaulfa1@gmail.com \\ I Gusti Ayu Indah Triana Juliari \\ English Language Education, Dwijendra University \\ e-mail: indahtriana@gmail.com
}

\begin{abstract}
This research aimed to improve the tenth grade students' reading comprehension by using POSSE strategy in SMK PGRI 2 Denpasar. It was an action research study which consisted of two cycles. The subjects of the research were students of X grade AK2 of SMK PGRI 2 Denpasar in the academic year 2019/2020. The qualitative data were collected by anlyzing the results of observation and interviewed the students on the learning process. The procedure of the research consisted of some stages, namely: planning, action, observation, and reflection. The instruments used of this research were observation sheet, interview guide, and tests. The method of collecting data were used interview, documentation, observation and test. The results of this research showed that the use of POSSE strategy was succesfully improve the students' reading comprehension. Based on the quantitative data, the students' mean scores for the reading comprehension improved from 55 in pre-test to 69 in post test 1 and 79 in post test 2. Meanwhile, from interviewed the students about the use of POSSE strategy showed that it helped the students to understand narrative text and helped them enrich their vocabulary knowledge. Besides that, the use of POSSE strategy could attract their attention in teaching and learning process.
\end{abstract}

Keywords: Reading Comprehension, Narrative Text, POSSE strategy.

Abstrak
Tujuan dari penelitian ini adalah untuk meningkatkan pemahaman membaca siswa kelas sepuluh dengan menggunakan strategi POSSE di SMK PGRI 2 Denpasar. Penelitian ini adalah penelitian tindakan kelas yang terdiri dari 2 skilus. Subjek penelitian ini adalah terdiri dari 35 siswa kelas X AK2 di SMK PGRI 2 Denpasar tahun ajaran 2019/2020. Data kualitatif dikumpulkan melalui menganalisis hasil observasi dan interview siswa terhadap proses pembelajaran. Prosedur penelitian terdiri dari beberapa tahapan yaitu perencanaan, tindakan, observasi dan refleksi. Instrument dari penelitian ini menggunakan lembar observasi, pedoman wawancara, dan tes. Pengumpulan data menggunakan metode wawancara, dokumentasi, observasi, dan tes evaluasi. Hasil penelitian ini menunjukkan bahwa penggunaan strategi POSSE berhasil untuk meningkatkan pemahaman membaca siswa. Berdasarkan data kuantitatif, nilai rata-rata siswa untuk pemahaman membaca meningkat dari 55 di pre-test, menja1di 69 di post-test 1, dan 79 di post-test 2 . Sementara itu, hasil wawancara para siswa tentang penggunaan strategi POSSE menunjukkan bahwa dapat membantu siswa untuk memahami teks naratif dan membantu mereka memperbanyak pengetahuan kosa kata. Selain itu, penggunaan strategi POSSE dapat menarik perhatian mereka dalam proses belajar mengajar.

Kata Kunci: Pemahaman membaca, teks naratif, strategi POSSE

\section{INTRODUCTION}

Language is the most important aspect in the life to human beings. According to
Aryanika (2016) In essence, language is signs and symbols that represent something that is expressed, both spoken and written 
(Swarniti \& Yuniari, 2019). Indonesia is one of the countries using English as a foreign language. The people use language to express their thoughts and emotions to make sense of complex and abstract thought, to learn to communicate with others, to fulfill our wants and needs, as well as to establish rules and maintain culture. Nowadays, the Department of Education takes it in national curriculum and also takes this language as one of the compulsory subjects of the formal education that must be learned by all students in Indonesia, from the elementary school up to the university, and business.

Reading is very important skill that should be mastered by students of senior high school because reading could make the people get information from what they read, and information from a text, it needs a thinking process in order to be able to reach the comprehension. Reading is a fluent process of readers combining information from a text and their own background knowledge to build meaning. Actually, reading skill was very important for students such as; the students can get information from they read, the students could add their knowledge, students could enlarge the way of their thinking by reading any text. So the students should have skill in reading to add their information and enrich their knowledge. (David, 2003:68)

As stated by Darmayenti et al (2017) Reading Comprehension is one of the skills which are taught in English subject of curriculum 2013. Based on the curriculum, the competency standard of reading for Senior High School of expects that the students are able to comprehend the short functional texts such as recount, narrative, descriptive, analytical exposition and procedure text in the daily context. It means after learning reading, the students must be able to comprehend the texts easily include the definition, main ideas, content of the text, generic structure, and the language feature of the text.

Based on preliminary observation, the unsatisfactory results of the students' reading comprehension were caused by several following factors. First, most students did not know the meaning of many words found in the text. Second, students were not able to comprehend the content of texts. It made them difficult to determine the important information such as topic, stated and unstated details, and references. Third, students did not read correctly. They were not taught reading strategies to comprehend the text effectively. Fourth, the teacher still used a conventional teaching method. She would shortly explain the text and asked students to answer questions related to the text. Finally, students felt unmotivated to do it. It was not effective enough to promote language acquisition. All those problems need to be solved because they gave impact on students' reading achievement which was low.

Based on curriculum in SMK PGRI 2 Denpasar, the ideal criterion of students for each indicator in one basic competence is 
$75 \%$. It means the minimum completeness criteria (KKM) of the students that is created by the teacher is 70 . The students' problem was caused by several factors internally and externally. The internal factors came from the students themselves. The students were not interested in reading activity. It was showed when they asked to read the text they were lazy and only read the text without knowing what they have read. And then, external factors come from the teacher. The teacher was still used a conventional teaching strategy. Teacher usually asked the students to translated the whole reading material or the teacher would shortly explain the text in the textbook and asked students to answer questions related to the text. In short, the teacher did not let their students to analyze and understand the meaning. Finally, students felt unmotivated and bored to do it. It was not effective enough to promote language acquisition. All those problems need to be solved because they give impact on student's reading achievement.

A teaching method or strategy needs to be implemented to solve those problems. Harmer (2001) said that teaching reading is taught from elementary school to university by using many kinds of strategies applied by English teacher. The strategy used should be a strategy that involves the students in the process of reading activity; therefore, the students will experience the learning and learn how to comprehend the text.
According to Westwood (2008) POSSE strategy is a reading comprehension strategy that combines text structure mapping, activation of prior knowledge and reciprocal teaching. POSSE strategy was designed to activate student's prior knowledge about the topic and to link it with new information contained in the text. The five letters in the acronym of POSSE strategy is stand for Predict, Organize, Search, Summarize, and Evaluate. As stated by Arianti and Tiarina (2014) support this by saying that POSSE was a multistep teaching strategy that not only assists students in activating the prior knowledge, but also encourages them to organize their existing knowledge and structure, and then summarize and elaborate on the connections between what they already knew and what they have learned.

The research problem could be concisely formulated as follows: Could the use of POSSE strategy improve the students' reading comprehension in narrative text at the tenth grade students of SMK PGRI 2 Denpasar in the academic year 2019/2020? In order to make present study has direction, there must be an objective that the researcher wants to achieve through the research conducted. Based on the question in research problem, the objective of this present study is to know the use of POSSE strategy could improve the students' reading comprehension in narrative text at the tenth grade students of SMK PGRI 2 Denpasar in the academic year 2019/2020. 
Therefore, the findings of the research are expected to indicate the result of the study is expected to be beneficial for teacher and students even other researchers; moreover, it could provide both theoretical as well as practical significance which are described as follows:

Theoretically, to help the researcher to find out the alternative way of teaching reading especially narrative and to produce the relevant and valid knowledge for their class to improve their teaching. Students get the case of organizing ideas or the information they have a coherent into a text narrative. Teachers know exactly the needs and problem faced by English language learning by students. Furthermore, they could provide appropriate measures to overcome them.

Practically, for the students will be expected to help students in increasing their skill in English especially in reading comprehension and hopefully can increase student's motivation in learning reading. For the teacher, obtains alternative use strategies in learning to read, especially reading comprehension and can modify it, and therefore students are encouraged to more easily understand the contents of the reading in learning process. And for the other researcher will be a form of devotion and application of knowledge, as well as providing learning experiences to researcher of the phenomena in schools learning material about reading comprehension.
It aims to find the gaps, strength, and weakness. It is helpful for this research to fill in the gaps and to be a different research (Wayan Swarniti, 2019).

\section{RESEARCH METHOD}

The method used in this research was classroom action research. The subjects of this research were the tenth grade students of SMK PGRI 2 Denpasar. It was located at Lempuyang Street Block Bromo No 11/1. The researcher chose $\mathrm{X}$ AK2 class as the subject of this study. This class consisted of 35 students. There were 5 males and 30 females students. In this action study, the teaching and learning process were divided into two cycles. In choosing the subject of this study, the researcher used purposive sampling. Purposive sampling was the process of selecting sample by taking subject that is not based on the level or area, but it was taken based on the specific purpose (Arikunto, 2010). The reason of the researcher chose this class because the mean score of this class was under the average in minimum completeness criteria (KKM). The minimum completeness criteria (KKM) in this class were 70 . Besides that, the students were difficult in identifying information on the texts, topic, main idea, and information on the narrative text.

According to Burns (2010), there were four procedures in doing this classroom action research, namely: planning, action, observation and reflection.

1. Planning 
In this first stage, the researcher identifies and analyzes the problems or issues and developed a plan in order to bring improvement in students' reading comprehension.

2. Action

In the stage of action, the students were teaching with the language skill of reading through the POSSE strategy. The kind of the text was chose based on the SK/KD (Standard of Competence and Basic Competence) in the second semester. The narrative texts are chose as the main materials. Some lesson plans are implementing by following the steps of POSSE strategy.

3. Observation

Observation was done to collect data namely, teacher and students activity during the teaching learning process. In this section the researcher was an observer for English teacher and the students of the class. The observation sheet and the students' score were making to collect the data of observation.

4. Reflection

Reflection was a feedback process from the action. In this final step, the researcher were reflecting, evaluating, describing, and providing explanation of the impact of POSSE strategy on the students' achievement in reading comprehension. Reflection was also used to help teacher to make decision. The teacher and researcher analyze all recording information learning process.

There were some instruments used in this research namely:

1.Observation sheet

Observation sheet was used to observe all activity happened during the teaching learning process.

2.Test

To get the data the researcher gave test. There were two tests used in this research, namely Pre-Test, Post-Test 1 and PostTest 2. The test was in the form of multiple choice questions.

3.Lesson Plan

Based on Chatib (2014) lesson plan was defined as a planning made by the teacher before teaching.

4.Interview Guide

Interview was conversation or dialogues with specific intentions. Conversation was conducted by the two parties, namely the interviewers who ask questions and interviews that provide answer to question that were either directly or indirectly. 
There were three techniques of data collecting applied in this study; they were observation, interview and test.

1. The researcher did the observation directly toward English teaching and learning process in the tenth grade students of SMK PGRI 2 Denpasar./1;; ;

2. Interview was applied for the English teacher before the classroom action research and after classroom action research.

3. Test was a process to measure students' ability and knowledge about material that is given, competence, intelligence, and talent that could belong to individual or group (Trianto:2007).

\section{FINDING AND DISCUSSION}

The researcher conducted interview with the students with the use of POSSE to improve reading comprehension at the tenth grade students of SMK PGRI 2 Denpasar and the researcher asked of some are students about POSSE strategy to improve reading comprehension and the some are students answer about the story narrative text, the first some there are students to say like to discussion about material but didn't understand some meaning of words, and some of students could not read text, and the students still lack vocabulary. It was found that the students really. They said that their English was not good. They could not read the English word or sentences correctly, they have difficulty to understand the narrative text and the students still lacked to reading in English, and they lacked of vocabulary because when the researcher told the students to retell the story they only use those words, for example Legend of Malin Kundang and Cinderella.

The improvement students reading comprehension could be seen by the result students' score reading comprehension in pre-test, post-test I, and post-test II. The result of this research support by observation sheet and interview that had been finished. The test consists of 20 questions. The text was multiple choices in narrative text form. The test was given to 35 students at the tenth grade students of SMK PGRI 2 Denpasar. The function of pre-test was to know their background knowledge.

The means score of pre-test was 55 from 35 students. However, the percentage of students get good categories in reading comprehension SMK PGRI 2 Denpasar was 28.6\%. Then the minimum completeness criteria was 70 . The result means score of post-test 1 was 69 improved $65.7 \%$ got good categories from pre-test, thus in this cycle the students were unfamiliar with using POSSE strategy yet, so they found some difficulties in doing this strategy. It could conclude that the students were not clear enough in implying the concept POSSE strategy. During cycle II the problem in cycle I was clear, the students were familiar and able to use POSSE strategy. The result 
means score of post-test 2 showed a better improvement. The improvement was $85.7 \%$ got very good categories from 35 students. The students had become more familiar with this strategy. Students' abilities in reading comprehension were excellent and very good categories. There were not students achieved poor.

Table 1. The improvement of the students means score:

\begin{tabular}{|c|c|c|}
\hline Type of Test & Means Score & Categories \\
\hline Pre-Test & 55 & Moderate \\
\hline Post-Test 1 & 69 & Good \\
\hline Post-Test 2 & 79 & Very Good \\
\hline
\end{tabular}

Chart 1. The improvement of the students means score:

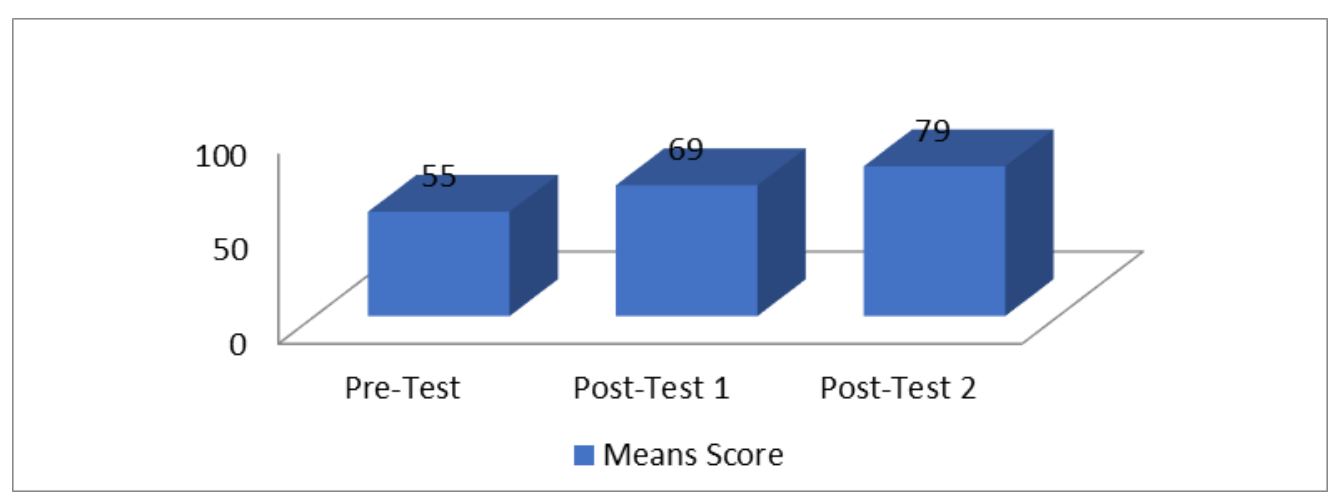

\section{CONCLUSION AND SUGGESTION}

Based on the findings and the discussion this has been explained above. It could be conclude that the use of POSSE strategy could improve the students' reading comprehension. The subjects of the study were at the tenth grade students of SMK PGRI 2 Denpasar in the academic year 2019/2020. It could be seen that classroom action research this study was started by doing four interconnected activities such as planning, action, observation, and reflection.
This research consisted of two sessions those were session 1 and 2 .

There were two cycles conducted during the present study and each cycle consisted of two sessions. During the study, the researcher has administered pre-test and post-test to the tenth grade students' of SMK PGRI 2 Denpasar. It could be seen that the means score of cycle I and cycle II respectively were 69 and 79; it clearly showed a significance improvement. In addition the result of last post-test showed all of the students if the study had achieved 
the minimum score criterion of SMK PGRI

2 Denpasar.

In conclusions the findings of the main data in this present study was in line with the existing supporting data which revealed the use of POSSE strategy in teaching reading comprehension at the tenth grade students of SMK PGRI 2 Denpasar in the academic year 2019/2020 could be improved.

\section{RERERENCES}

Arianti, G., \& Tiarina, Y. (2014).Teaching reading analytical exposition text to senior high school students by using posse (predict, organize, search,

summarize, evaluate) strategy. Journal of English Language Teaching,

3(1), 195-201.

Arikunto. (2010). Prosedur Penelitian: Suatu Pendekatan Praktek. Jakarta: Rineka Cipta.

Aryanika, S. English Education:Jurnal Tadris Bahasa Inggris, 9 (1), 2016,215.

Burns, A. 2010.Doing Action Research in Language Teaching: A Guide for practitioners. NY: Routledge. Pp.196.

Darmayenti, \& Kustati, M. 2017. Enhancing Islamic Students ${ }^{\text {ee }} \quad$ Reading

\author{
Comprehension through Predict \\ Organize Search Summarize \\ Evaluate Strategy. Al-Ta'lim \\ Journal. 24 (1): 1-8.
}

Harmer, J. 2001.The Practice of English Language Teaching Third Editiotion Cambridge: Longman Company.

Julian Hermida, 2001. The What, Why and How of Classroom Action Research JoSoTL Vol. 2, Number 1, (2001).

Nunan, D. 2003. Practical Language English Teaching. p.68.

Santika, I Gusti Ngurah. 2017. Kepala Sekolah Dalam Konsep Kepemimpinan Pendidikan: Suatu Kajian Teoritis. Widya Accarya. 7 (1).

Swarniti, N. W., \& Yuniari, N. M. (2019). Keberadaan Leksikon Pohon Langka di Denpasar: Studi Ekolinguistik. Seminar Nasional INOBALI 2019 Inovasi Baru Dalam Penelitian Sains, Teknologi Dan Humaniora, 405-411. https://eproceeding.undwi.ac.id/index. php/inobali/article/view/180

Wayan Swarniti, N. (2019). The Translation Procedures of Bible Translation. 5(2), 187-196.

https://doi.org/10.22225/jr.5.2.1277.18 7-196

Trianto. 2007. Model-model Pembelajaran Inovatif Berorientasi Kontstruktivistik, p.62

Westwood P, 2008. What Teachers Need To Know about Reading And Writing Difficulties, p.45. 